\title{
Distribution and Transmission of Iris yellow spot virus
}

\author{
A. Kritzman, M. Lampel, B. Raccah, and A. Gera, Department of Virology, Agricultural Research Organization, \\ The Volcani Center, Bet Dagan 50250, Israel
}

\begin{abstract}
Kritzman, A., Lampel, M., Raccah, B., and Gera, A. 2001. Distribution and transmission of Iris yellow spot virus. Plant Dis. 85:838-842.

Iris yellow spot virus (IYSV), a new tospovirus associated with a disease in onion (Allium cepa) that is known to growers in Israel as "straw bleaching," was identified and further characterized by host range, serology, electron microscopy, and molecular analysis of the nucleocapsid gene. The transmissibility of IYSV by Thrips tabaci and Frankliniella occidentalis was studied. IYSV was efficiently transmitted by $T$. tabaci from infected to healthy onion seedlings and leaf pieces. Two biotypes of $F$. occidentalis, collected from two different locations in Israel, failed to transmit the virus. Surveys to relate the incidence of thrips populations to that of IYSV were conducted in onion fields. They revealed that the onion thrips T. tabaci was the predominant thrips species, and that its incidence was strongly related to that of IYSV. Forty-five percent of the thrips population collected from IYSV-infected onion and garlic fields in Israel transmitted the virus. IYSV was not transmitted to onion seedlings from infected mother plants through the seed, and was not located in bulbs of infected plants.
\end{abstract}

The genus Tospovirus includes Tomato spotted wilt virus (TSWV) and several other species (11). They are transmitted by thrips (Thysanoptera: Thripidae) in a propagative manner (22). Thrips can transmit tospoviruses only if they acquire the virus by their larval stage, especially by the first instar. At present, at least eight species of thrips are known to transmit tospoviruses $(16,21)$.

Of 12 tospovirus species described so far, three were reported in Israel: TSWV (2), Impatiens necrotic spot virus (INSV) (10) and Iris yellow spot virus (IYSV) (7). The last was detected in Hippeastrum hybridum cv. Orange Souvereign; in onion (Allium cepa), and recently in lisianthus (Eustoma russellianum) (12). The virus in the latter study was identified by serology and sequence analysis.

IYSV was associated with a disease in onion known to growers in Israel as "straw bleaching." The incidence of the disease often reached 50 to $60 \%$, resulting in heavy losses of onion-bulb production (7).

Two species of tospovirus vectors are found in Israel: Frankliniella occidentalis and Thrips tabaci. The first is responsible for a recent TSWV epidemic (8). For effective integrated management of tospoviruses in Israel, information on virus incidence and vector identity is necessary. The goals of the present study were to help

Corresponding author: A. Gera

E-mail: abdeg@netvision.net.il

Accepted for publication 18 April 2001

Publication no. D-2001-0611-03R

(C) 2001 The American Phytopathological Society distinguish the IYSV isolates from onion and $H$. hybridum; to study the biological transmission of IYSV, and to identify the thrips vector and its efficiency in transmitting the virus. A preliminary report on this work has been published (7).

\section{MATERIALS AND METHODS}

Virus characterization. IYSV was isolated from A. cepa and H. hybridum collected in the Bet-Shean Valley in Israel. The virus was maintained in Nicotiana benthamiana Domin. To determine host range, samples of IYSV-infected plants were homogenized in $0.01 \mathrm{M}$ sodium phosphate buffer, $\mathrm{pH} 7.0$, containing $0.1 \%$ sodium sulfite, and the sap was inoculated to a number of host plants, predusted with carborundum. Plants were kept under greenhouse conditions, observed for symptom expression, and assayed by enzymelinked immunosorbent assay (ELISA).

Ultrathin sections $(2 \times 1 \mathrm{~mm})$ were excised from symptomatic young leaves of onion, $H$. hybridum and $N$. benthamiana. They were fixed, dehydrated, embedded, and polymerized as described by Orion and Franck (17). Sectioned material was stained with uranyl acetate followed by lead nitrate, and examined for viruses by electron microscopy.

Purification of IYSV nucleocapsids (NC) was as described previously (12). Samples from purified preparations were electrophoresed in SDS polyacrylamide gels. The protein bands were stained with $0.1 \%$ Coomassie Brilliant Blue or electroblotted to nitrocellulose and probed with IYSV antiserum (9).

Viral RNA extraction from systemically infected $N$. benthamiana, cDNA cloning, determination of the nucleotide sequence, and sequence analysis (1) were performed as described previously (12).

Virus distribution in onion plants. Eight well-developed onion plants, naturally infected with IYSV, were used to determine virus distribution within the leaves. Five leaves of each plant were each divided into four equal segments. Each segment was sampled $(0.25 \mathrm{~g})$ and tested for IYSV by double-antibody sandwich (DAS) ELISA. Bulb and root samples were also tested. ELISA was carried out with a polyclonal antibody against the NC proteins prepared in our laboratory (9). Leaf disks and pieces were homogenized in a microcentrifuge tube with $0.3 \mathrm{ml}$ of extraction buffer ( $2 \%$ polyvinylpyrrolidone in phosphate-buffered saline (PBS)-Tween). Absorbence values at least three times as high as those of the healthy controls were considered positive (6).

Seed and bulb transmission. Mature seeds were harvested from naturally infected A. cepa that showed severe necrotic symptoms. The presence of IYSV in plants designated as seed sources was confirmed by ELISA prior to seed collection. Noninfested seeds were collected from healthy plants and served as controls. Seeds were washed in running tap water and dried at room temperature. Seedlings produced from onion seeds were germinated in Speedling trays and subsequently transplanted to plastic pots in which they were grown for 5 to 8 weeks before being tested for IYSV. Five-hundred-thirty-five seedlings were grown and observed weekly for IYSV symptoms, and assayed by ELISA.

Maintenance of thrips field populations and transmission assays. Experiments were conducted during the 1999/ 2000 season in Dovrat, the Yizre'el Valley, Israel. Onion 'Riverside' seeds were sown on February 20, and bulbs were harvested during July. A randomized complete block design with four replications (each of $2 \times$ $10 \mathrm{~m}$ ) was used. Ten plants from each block were used for thrips counting. Both larvae and adults of $T$. tabaci were included. Five counts were taken at 2 -week intervals, starting in mid-April.

Populations of $T$. tabaci were collected from onion and garlic grown in several different locations in Israel. F. occidentalis populations collected from mango in Bet Dagan and from sunflowers in the Arava Valley, Israel, were reared in the laboratory. Adult thrips were confined for up to 4 days on bean pods to lay eggs. Once the eggs had hatched, the larvae were collected for up to $12 \mathrm{~h}$ and used for transmission. 
Three experimental transmission designs were used. The first involved laboratory populations of T. tabaci or F. occidentalis, 4 to $12 \mathrm{~h}$ posthatching. First-instar larvae were reared on naturally infected onions (as tested by ELISA) and allowed to move freely to healthy onion seedlings (grown from seeds and tested for IYSV by ELISA) in the same cage. Healthy plants exposed to thrips for inoculation access feeding were kept under greenhouse conditions and observed for symptom expression for 4 weeks. Virus presence was ascertained by ELISA.

In the second experimental transmission design, first-instar larvae of two $F$. occidentalis populations collected from mango in Bet Dagan and from sunflowers in the Arava Valley were placed for $24 \mathrm{~h}$ acquisition access feeding on IYSV-infected onions or Emilia sonchifolia. They were then transferred to bean pods for the completion of their developmental cycle ( $12 \mathrm{~d}$ on average). Then, the insects were placed on healthy onion or E. sonchifolia leaf pieces for a subsequent inoculation access feeding period of $48 \mathrm{~h}$.

In the third transmission design, populations of $T$. tabaci larvae and adults were collected from naturally IYSV-infected onion fields. Onion seedlings grown from seeds and testing negative for IYSV by ELISA were used for thrips transmission experiments. A single adult thrips was placed on each healthy seedling leaf piece or healthy E. sonchifolia leaf disk

for one or two cycles following inoculation access feeding periods of 2 days each. Virus presence was later ascertained by ELISA.

\section{RESULTS}

Virus characterization. Symptoms of the virus in naturally infected $A$. cepa include straw-colored, chlorotic, and necrotic lesions on leaves (Fig. 1A). In $H$. hybridum, chlorotic ring spots on leaves were observed (Fig. 1B). In order to verify that the virus used in this study is, in fact, IYSV, the causal agent was characterized at the biological, serological, and molecular level.

Plant species that had been used previously to determine the host range of IYSV $(4,12,20)$ were inoculated mechanically with the virus from both onion and $H$. hybridum. These plants were observed for symptom development, and infection was ascertained by DAS-ELISA. Only $N$. benthamiana and E. russellianum became systemically infected with IYSV after mechanical inoculation. On inoculated leaves of Chenopodium quinoa, C. amaranticolor, and Gomphrena globosa, necrotic local lesions developed within 4-5 days post inoculation. In successive mechanical transmission tests from $N$. benthamiana, necrotic local lesions developed on E. sonchifolia, Datura stramonium and Petunia hybrida. The virus did not infect Cucumis sativus, Lycopersicon esculentum, $N$. tabacum, $N$. glutinosa or $N$. rustica. Mean ELISA $(\mathrm{n}=8)$ values $\left(\mathrm{OD}_{405}\right)$ of samples from field-infected onion, $H$. hybridum and mechanically infected $N$. benthamiana diluted $1: 10$, were $1.75,0.65$, and 1.85 , respectively. The mean ELISA values $(n=8)$ of the negative healthy controls were $0.08,0.05$, and 0.08 , respectively.

To confirm symptom development and Koch's postulates, virus-free onion and $H$. hybridum seedlings were inoculated mechanically with plant sap from naturally infected plants, or with purified virus obtained from infected $N$. benthamiana. Four out of eight mechanically infected $H$. hybridum plants developed symptoms identical to those observed on naturally infected plants. No visual symptoms developed on mechanically inoculated onion, but virus was detected by ELISA in all symptomless inoculated plants $(20 / 20)$.
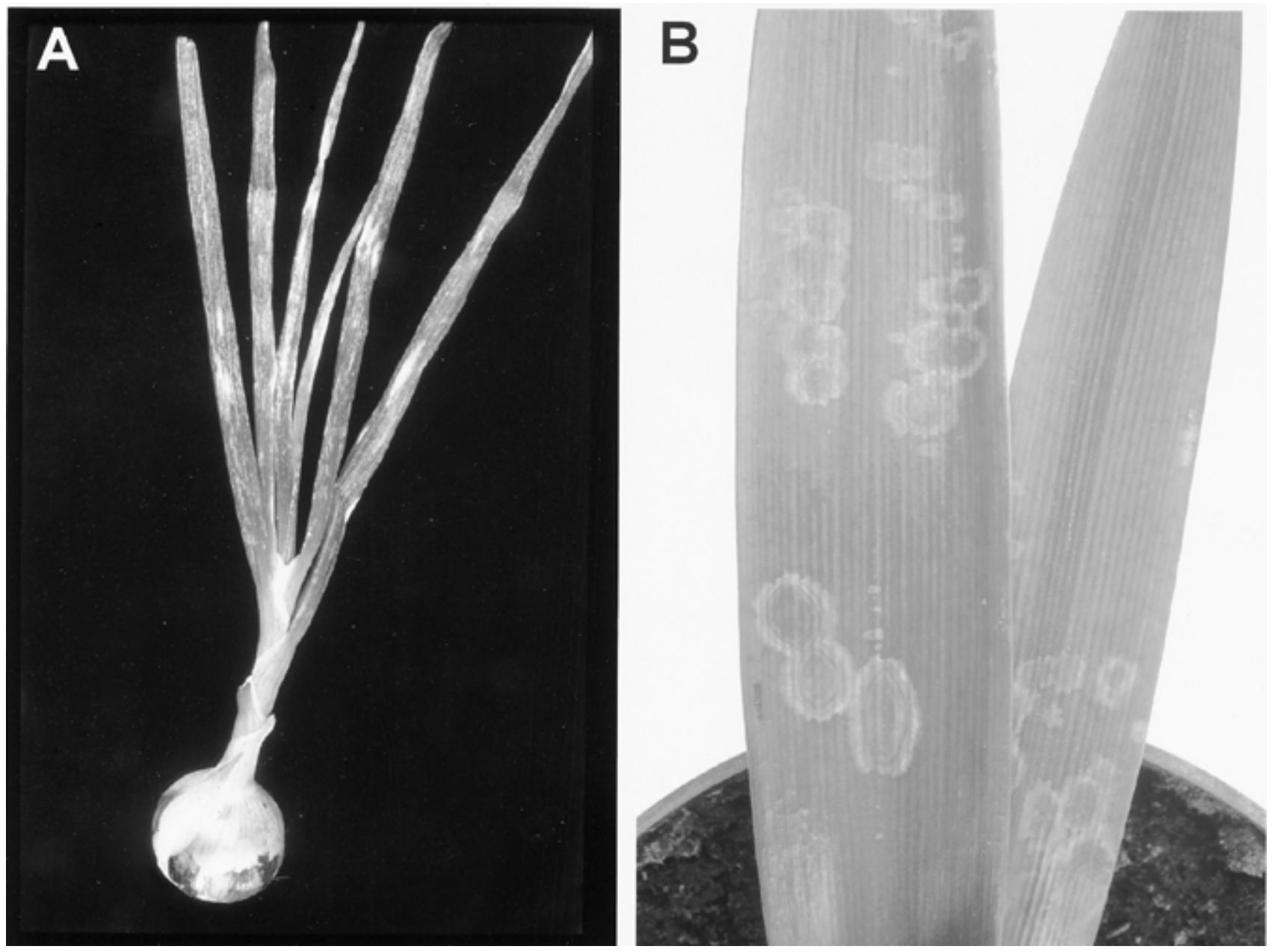

Fig. 1. Symptoms of Iris yellow spot virus (IYSV) on A, onion, and B, Hippeastrum. 
In ultrathin sections of naturally infected $H$. hybridum and mechanically inoculated $N$. benthamiana, numerous spherical particles were always observed within membrane-bound vesicles (Fig. 2). The sections showed tospovirus-like particles and membranous structures that were not observed in noninfected controls (Fig. 2A and B). Membranous structures were observed in cells of naturally infected onion, but no tospovirus-like particles were observed (results not shown).

Purified IYSV NC material, from onion and $H$. hybridum, when denatured with SDS and analyzed by polyacrylamide gel electrophoresis, revealed one major polypeptide band (Fig. 3A, lanes 1 and 2). The $M_{\mathrm{r}}$ of the $\mathrm{N}$ protein was estimated to be 32,500 Da. Immunoblots with the antiserum against the IYSV NC revealed a clear and strong reaction with the polypeptide corresponding to the $\mathrm{N}$ protein (Fig. 3B).

The $\mathrm{N}$ gene of IYSV from onion was amplified by RT-PCR. Fragments of the expected size (850 nucleotides) were subjected directly to sequence analysis. In addition, the fragments were cloned and three selected recombinant plasmids were sequenced. Multiple alignments of the deduced NC amino acid sequence of IYSV from onion showed $99 \%$ identity with IYSV from lisianthus, deposited in the GenBank database under the accession number AF271219 (Fig. 4). These two IYSV isolates showed 96 and $91 \%$ identity, respectively, with those of the Dutch (IYSV-NL, AF001387) and Brazilian (IYSV-Br, AF067070) strains (data not shown).

Virus distribution in onion plants. In order to develop a reliable test protocol for onion, we examined the virus distribution in the various plant parts as well as virus transmission during vegetative propagation. Results of the virus distribution measurements within naturally infected onion plants are summarized in Table 1 . Although the virus was detected in all segments of various leaves, the distribution of virus was not uniform within infected plants. Higher concentrations were obtained consistently in the internal leaves and in leaf segments close to the bulb. Attempts to detect the virus in onion roots or bulbs of infected plants were unsuccessful.

Seed and bulb transmission. No visible symptoms were observed in onion seedlings grown from seeds harvested from infected plants that were naturally infected with IYSV, and none of the seedlings were found to be infected with IYSV as determined by ELISA (0/535), up to 8 weeks after germination. These results indicate that the virus is not seed-borne. In addition, there were no significant differences in germination between seeds collected from infected plants $(80 \%)$ and those collected from noninfected plants (83\%). Moreover, when onion bulbs taken from symptomatic plants that tested positive for IYSV by ELISA were planted, no leaf symptoms developed, and all leaf samples tested by ELISA were negative $(n=25)$.

Thrips transmission. Surveys to relate the incidence of thrips populations to that of IYSV were conducted in onion fields. These surveys showed that the onion thrips, $T$. tabaci was the predominant thrips species and that its incidence was strongly related to that of IYSV (Table 2). The mean numbers of $T$. tabaci per plant in an infected onion field, counted at 2-week intervals starting 2 months after sowing, were $13,64,48,21$, and 15 (Table 2). The proportions of vectors among the total thrips populations collected from infected onion and garlic fields were 31 and $43 \%$, respectively (Table 3 ).

To confirm virus transmission by thrips, a colony of $T$. tabaci larvae grown in our laboratory was introduced onto naturally infected A. cepa plants, and virus-free onion seedlings were exposed to adults that developed on those plants. T. tabaci transmitted the virus to 12 out of 20 plants, as confirmed by ELISA. When the population of $F$. occidentalis from mango in Bet Dagan (an efficient transmitter of TSWV) was used, none of 20 tested onions became infected.
Two $F$. occidentalis populations were collected, one from mango in Bet Dagan (n = 65), one from sunflowers in the Arava Valley $(\mathrm{n}=78)$, an efficient and a poor transmitter of populations of TSWV, respectively. They failed to transmit the virus from $E$. sonchifolia to onion and $E$. sonchifolia leaf pieces.

T. tabaci adults and larvae collected from infected onion fields in different locations in Israel were 33 to $50 \%$ efficient in transmitting IYSV to onion as confirmed by ELISA (Table 4).

\section{DISCUSSION}

Our findings show that the new disease of onions and Hippeastrum found in Israel is caused by IYSV. The virus was characterized by host range, serology, and electron microscopy. Virus identification was based on reactivity with specific polyclonal antibodies against the IYSV NC, and by nucleotide sequence analysis of the $\mathrm{NC}$

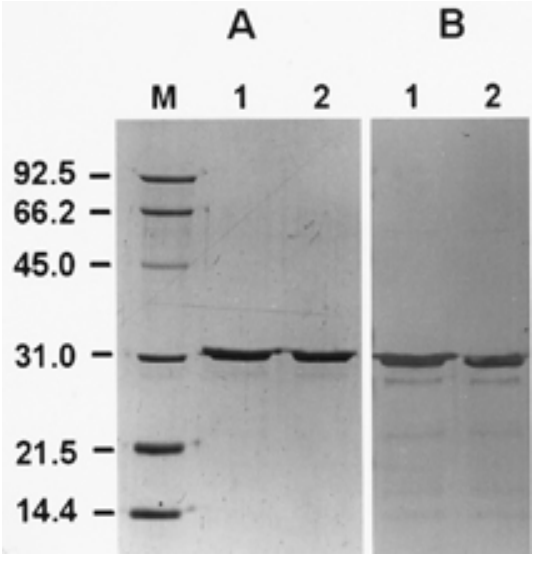

Fig. 3. Sodium dodecyl sulfate (SDS)polyacrylamide gel electrophoresis and immunoblots of the nucleocapsid (NC) proteins of Iris yellow spot virus (IYSV). Panel A stained with Coomassie Brilliant Blue. (M) molecular weight markers: lanes 1 and 2, N-proteins of IYSV from onion and Hippeastrum, respectively. B, gel was blotted on a membrane and probed with the antiserum against IYSV nucleocapsid (diluted 1:2000).
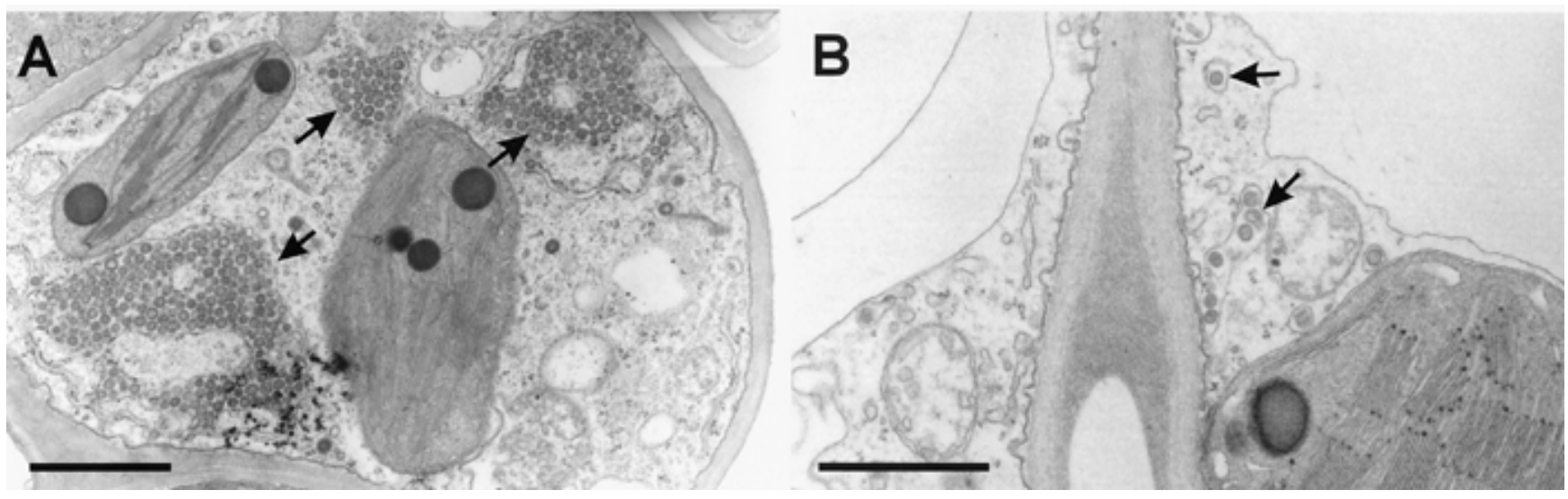

Fig. 2. Electron micrograph of Iris yellow spot virus (IYSV) virions in thin sections of A, mechanically inoculated Nicotiana benthamiana, and $\mathbf{B}$, Hippeastrum. $(\mathrm{Bar}=500 \mathrm{~nm}$. 
gene. This newly emerged disease has a worldwide distribution: IYSV was isolated from iris in the Netherlands (4), from onion in Brazil (20), and from lisianthus in Israel (12). Unlike the type member of the tospovirus group, IYSV apparently has a relatively narrow host range. The virus induced local symptoms in $C$. quinoa, $G$. globosa, D. stramonium, and $P$. hybrida, and systemic reaction in $N$. benthamiana and E. sonchifolia. Although typical viral symptoms were produced in Hippeastrum, difficulties were encountered in producing the disease symptoms in onion under experimental conditions. Pozzer et al. (20) also encountered similar difficulties in confirming Koch's postulates in studies intended to characterize IYSV in onion.

The Israeli isolates of IYSV obtained from onion and Hippeastrum were serologically identical. Both reacted with polyclonal antibodies produced against the $\mathrm{NC}$ protein in ELISA and immunoblots. The $M_{\mathrm{r}}$ of $32.5 \mathrm{kD}$ observed in SDS-PAGE for IYSV nucleocapsid was consistent with those published for the Dutch isolate (4).

Several studies $(13,18,19,24)$ showed distinct levels of specificity in thrips transmission of tospoviruses. These reports mentioned variation in transmissibility of TSWV, both for T. tabaci populations (3) and for $F$. occidentalis populations (23). Our results demonstrate that IYSV is transmitted by $T$. tabaci, and not by $F$. occidentalis populations. T. tabaci acquired and transmitted IYSV from infected onion plants. High rates of transmission by the field population of $T$. tabaci reflect the high proportion of viruliferous insects in the field. No transmission was observed by F. occidentalis. These results are similar to results obtained in Brazil (14), where $T$. tabaci was found to be the most important vector species of IYSV in onion. The failure of $F$. occidentalis to transmit IYSV may be attributed to a barrier preventing the infection of the salivary glands (21). Salivary glands must contain large amounts of virions for thrips to transmit the virus (15).

The virus distribution within the onion plant was uneven. The highest titers were in the inner leaves and near the bulb. That area is also most preferred by the thrips as a feeding site, and it offers the best opportunity for virus acquisition and/or infection by larvae and adults, respectively. The failure to detect the virus in bulbs or roots of infected onions and Hippeastrum, and the lack of virus transmission in the subsequent generation are similar to results obtained in iris (5). Both TSWV and INSV were detected, mainly in the inner symptomatic leaves of infected iris, and no virus was detected in the subsequent generation of TSWV- or IYSV-infected and symptomatic plants (5). Unlike IYSV in onion and iris, TSWV was detected in leaves, roots, bulbs, and some of the daughter bulbs, as well as in the subsequent generation of
Hippeastrum plants (5). The virus distribution observed within onion and Hippeastrum leaves in this study may reflect local infection incited by feeding thrips. The factors, which restrict the movement of the virus from leaves to bulb, are not yet known.

Previously we reported that TSWV antigens were readily detected by ELISA in seeds harvested from naturally infected vegetable and ornamentals (2), although we failed to show virus transmission. Our present results demonstrate that seeds harvested from IYSV infested onions do not transmit the virus to progeny plants. No visible symptoms were observed in seedlings up to two months after germination, and none of the seedlings were infected with IYSV as confirmed by ELISA. These results indicate that IYSV is not seedborne in onion.

The data, showing that neither seeds nor bulbs from infected onion plants serve as

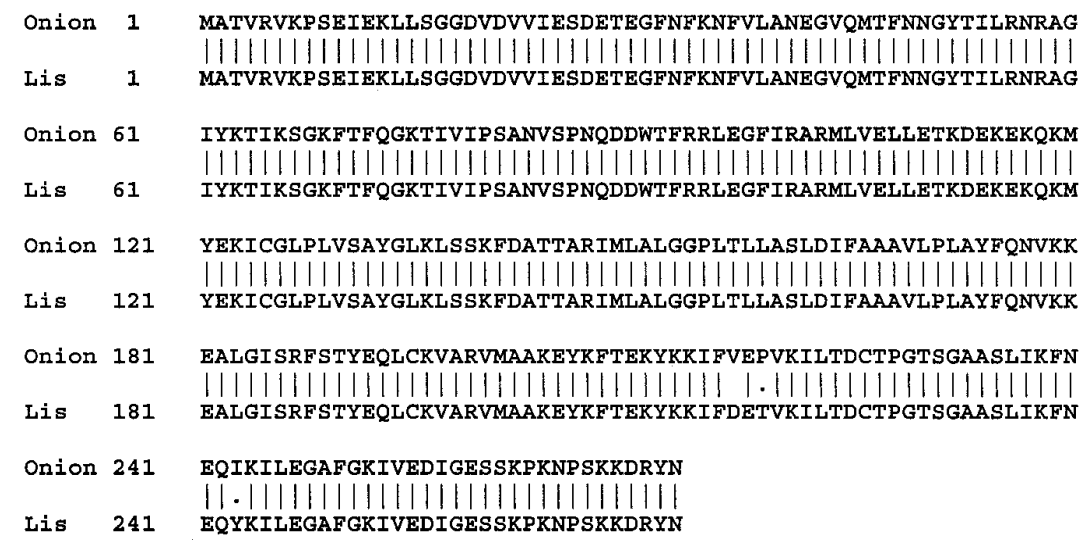

Fig. 4. Sequence alignments of nucleocapsid proteins of Iris yellow spot virus (IYSV) from onion and lisianthus (Lis).

Table 1. Distribution of Iris yellow spot virus (IYSV) in naturally infected onion leaves as determined by enzyme-linked immunosorbent assay (ELISA)

\begin{tabular}{cccccc}
\hline & \multicolumn{5}{c}{ ELISA values $\left(\mathbf{E}_{\mathbf{4 0 5}}\right)^{\mathbf{b}}$} \\
\cline { 2 - 6 } Slice position $^{\mathbf{a}}$ & Leaf $^{\mathbf{c}}$ \#I & Leaf \#II & Leaf \#III & Leaf \# IV & Leaf \# V \\
\hline A & $0.299 \pm 0.298$ & $0.412 \pm 0.429$ & $0.914 \pm 0.833$ & $0.593 \pm 0.676$ & $0.518 \pm 0.635$ \\
B & $0.228 \pm 0.227$ & $0.689 \pm 0.649$ & $1.218 \pm 0.987$ & $0.730 \pm 0.435$ & $0.656 \pm 0.835$ \\
C & $0.566 \pm 0.494$ & $1.038 \pm 0.749$ & $1.836 \pm 0.902$ & $1.703 \pm 0.624$ & $0.861 \pm 0.707$ \\
D & $1.860 \pm 0.673$ & $2.069 \pm 0.902$ & $2.706 \pm 0.156$ & $2.326 \pm 0.556$ & $1.895 \pm 0.772$ \\
\hline
\end{tabular}

${ }^{\text {a }}$ Slice A is the tip of the leaf, and slice D is closest to the bulb.

${ }^{\mathrm{b}}$ Mean values of eight different onion leaves, after subtraction of the corresponding healthy controls (0.030 to 0.080$)$

${ }^{c}$ Leaves I and V are the external and leaf III is the internal one.

Table 2. Mean numbers of thrips, and Iris yellow spot virus (IYSV) incidence in the field

\begin{tabular}{lccc}
\hline Date of count & Mean no. thrips per 10 plants $( \pm$ SD) & Virus incidence $^{\text {a }}$ & $(\%)$ \\
\hline $4 / 17 / 00$ & $130 \pm 53$ & $\mathrm{nt}$ & $\mathrm{nt}$ \\
$5 / 1 / 00$ & $642 \pm 195$ & $20 / 35$ & 57 \\
$5 / 15 / 00$ & $476 \pm 51$ & $\mathrm{nt}$ & $\mathrm{nt}$ \\
$5 / 29 / 00$ & $212 \pm 26$ & $\mathrm{nt}$ & $\mathrm{nt}$ \\
$6 / 12 / 00$ & $162 \pm 30$ & $12 / 20$ & 60 \\
\hline
\end{tabular}

a Virus incidence is the number of infected plants out of total plants tested; $n t=$ not tested.

Table 3. Transmission rates of Iris yellow spot virus (IYSV) by adult Thrips tabaci collected from infected onion fields and nearby garlic fields in the Jordan Valley

\begin{tabular}{lccccc}
\hline & \multicolumn{3}{c}{ Transmission rates by thrips collected from: } \\
\cline { 2 - 3 } \cline { 5 - 6 } \cline { 5 - 6 } & \multicolumn{2}{c}{ Naturally infected onions } & & \multicolumn{2}{c}{ Garlic field } \\
\cline { 2 - 3 } \cline { 5 - 6 } & No./total $^{\mathbf{a}}$ & $\mathbf{( \% )}$ & & No./total & $(\%)$ \\
\hline First transmission & $8 / 26$ & 30.8 & & $9 / 21$ & 42.9 \\
Second transmission & $3 / 12$ & 25 & & $4 / 11$ & 36.4 \\
\hline
\end{tabular}

a Denominator, number of leaf pieces of onion seedlings used: numerator, number of leaf pieces of onion seedlings infected, with one thrips per leaf piece. Inoculation access feeding time was 2 days. 
Table 4. Transmission rates of Iris yellow spot virus (IYSV) by adult Thrips tabaci collected as larvae or adults from infected onion fields grown in different location in Israel

\begin{tabular}{|c|c|c|c|c|}
\hline \multirow[b]{3}{*}{ Location } & \multicolumn{4}{|c|}{ Transmission rates by thrips collected as: ${ }^{\mathbf{a}}$} \\
\hline & \multicolumn{2}{|c|}{ Adults } & \multicolumn{2}{|c|}{ Larvae } \\
\hline & No./total ${ }^{b}$ & $(\%)$ & No./total ${ }^{\text {b }}$ & $(\%)$ \\
\hline Ein Harod & $16 / 37$ & $49.2 \%$ & $8 / 19$ & $42.1 \%$ \\
\hline Mitzpeh & $10 / 24$ & $47.9 \%$ & $8 / 18$ & $44.4 \%$ \\
\hline Yagor & $4 / 12$ & $33.3 \%$ & $2 / 4$ & $50.0 \%$ \\
\hline
\end{tabular}

a In all tests, only adults were used for transmission; inoculation access feeding was $48 \mathrm{~h}$.

${ }^{\mathrm{b}}$ Denominator: number of onion leaf pieces used; numerator: number of onion leaf pieces infected, with one thrips per leaf piece.

sources of IYSV for the subsequent generation, leaves thrips transmission as the manner in which this virus is transmitted. The overlapping growing seasons of both onion and Hippeastrum in BetShean Valley may explain the potential source of the virus. However, information on possible hosts for the vector and the virus within the natural vegetation would be essential to understand the sources of primary infection.

The outbreak of IYSV in Israel is associated with large populations of $T$. tabaci. However, despite the wide distribution of this insect in natural vegetation and various crops, outbreaks of the disease are limited to certain areas. The characterization of the virus in onion and the identification of its thrips vector provides valuable information to help growers to control the disease.

\section{ACKNOWLEDGMENTS}

A contribution came from the Agricultural Research Organization, the Volcani Center, Bet Dagan, Israel. No. 539/00 series. This work was supported in part by the United States-Israel Binational Agricultural Research and Development Fund (BARD).

\section{LITERATURE CITED}

1. Altschul, S. F., Gish, W., Miller, W., Myers, E. W., and Lipman, D. J. 1990. Basic local alignment search tool. J. Mol. Biol. 215:403410.

2. Antignus, Y., Lapidot, M., Ganaim, N., Cohen, J., Lachman, O., Pearlsman, A., Raccah, B., and Gera, A. 1997. Biological and molecular characterization of tomato spotted wilt virus in Israel. Phytoparasitica 25:319330 .

3. Chatzivassiliou, E. K., Nagata, T., Katis, N. I., and Peters, D., 1999. Transmission of tomato spotted wilt tospovirus by Thrips tabaci populations originating from leek. Plant Pathol. 48:700-706.

4. Cortês, I., Livieratos, J., Derks, A., Peters, D., and ent Fund Kormelink, R. 1998. Molecular and serological characterization of iris yellow spot virus, a new and distinct tospovirus species. Phytopathology 88:1276-1282.

5. Derks, A. F. L. M., and Lemmers, M. E. C. 1996. Detection of tospoviruses in bulbous crops and transmissibility by vegetative propagation. Acta Hortic. 432:132-137.

6. Frey, A., Di Canzio, J., and Zurakowski, D., 1998. A statistically defined endpoint titer determination method for immunoassays. J. Immunol. Methods 221: 35-41.

7. Gera, A., Cohen, J., Salomon, R., and Raccah, B. 1998a. Iris Yellow Spot Tospovirus detected in Onion (Allium cepa) in Israel. Plant Dis. 82:127.

8. Gera, A., Kritzman, A., Ganaim, N., and Raccah, B. 1998b. Transmission of tomato spotted wilt Tospovirus by F. occidentalis and analysis of the distribution of the virus in the field in Israel. Pages 25-29 in: Proc. Int. Sym. on Thysanoptera, 6 th.

9. Gera, A., Cohen, J., Kritzman, A., Beckelman, E., and Bar-Joseph, M. 1999. Production of diagnostic antibodies to plant viruses utilizing denatured coat proteins and booster immunization with partially purified virus. J. Plant Pathol. 81:189-192.

10. Gera, A., Kritzman, A., Cohen, J., and Raccah, B., 1999. First report of impatiens necrotic spot tospovirus (INSV) in Israel. Plant Dis. 83:587.

11. Goldbach, R., and Kuo, G. 1996. Introduction. In: International Symposium on Tospoviruses and Thrips of Floral and Vegetable Crops. Acta Hortic. 431:21-26.

12. Kritzman, A., Beckelman, H., Alexandrov, S., Cohen, J., Lampel, M., Zeidan, M., Raccah, B., and Gera, A. 2000. Lisianthus leaf necrosis: A new disease of lisianthus caused by Iris yellow spot virus. Plant Dis. 84:1185-1189.

13. Mau, R. F. L., Bautista, R., Cho, J. J., Ullman, D. E., Gusukuma-Minuto, L. R., and Custer, D. 1991. Factors affecting the epidemiology of TSWV in field crops: Comparative virus acquisition efficiency of vectors and suitability of alternate hosts to Frankliniella occidentalis (Pergande). In: Virus-Thrips-Plant Interaction of Tomato Spotted Wilt Virus. H. Hsu and R H. Lawson, eds. Pages 21-27 in: Proc. USDA Workshop, U. S. Dep. Agric. Agric. Res. Serv., ARS. 87.

14. Nagata, T., Almedia, A. L., de Resende, R. and de Avila, C. 1999a. The identification of the vector species of iris yellow spot tospovirus occurring in onion in Brazil. Plant Dis. 83:399.

15. Nagata, T., Inoue-Nagata, A. K., Smid, H. M., Goldbach, R., and Peters, D. 1999b. Tissue tropism affecting vector competence of Frankliniella occidentalis for tomato spotted wilt tospovirus. J. Gen. Virol. 80:507-515.

16. Nakahara, S., and Monteiro, R. C., 1999. Frankliniella zucchini (Thysanoptera: Thripidae), a new species and vector of tospovirus in Brazil. Proc. Entomol. Soc. Wash. 101:290294.

17. Orion, D., and Frank, A. 1990. An electron microscopy study of cell wall lysis by Meloidgyne javanica gelatinous matrix. Rev. Nematol. 13:105-107.

18. Paliwal, Y. C., 1974. Some properties and thrips transmission of tomato spotted wilt virus in Canada. Can. J. Bot. 52:1170-1182.

19. Paliwal, Y. C. 1976. Some characteristics of the thrips Frankliniella occidentalis vector relationship of tomato spotted wilt virus in Canada. Can. J. Bot. 54: 402-405.

20. Pozzer, L., Bezerra, I. C., Kormelink, R., Prins, M., Peters, D., Resende, R. de O., and de Avila, A. C. 1999. Characterization of a tospovirus isolate of iris yellow spot virus associated with a disease in onion fields in Brazil. Plant Dis. 83: 345-350.

21. Ullman, D. E., Cho, J. J., Mau, R .F. L., Westcot, D. M., and Custer, D. M. 1992. A midgut epithelial barrier to tomato spotted wilt virus acquisition by adult western flower thrips. Phytopathology 82:1333-1342.

22. Ullman, D. E., Cho, J. J., Mau, R. F. L., Hunter, W. B., Westcot, D. M., and Custer, D. M., 1992. Thrips-tomato spotted wilt virus interactions: Morphological, behavioral and cellular components influencing thrips transmission. Pages 195-240 in: Advances in Disease Vector Research. Vol. 9. Harris, K. F., ed. Springer-Verlag, New York.

23. Ullman, D. E., Sherwood, J. L., and German, T. L., 1997. Thrips as vectors of plant pathogens. Pages 539-565 in: Lewis T. (ed.), Thrips as Crop Pests. CAB International, Cambridge University Press, Cambridge, UK.

24. Van de Wetering, F., van der Hoek, M., Goldbach, R., Mollema, C., and Peters, D. 1999 Variation in tospovirus transmission between populations of Frankliniella occidentalis (Thysanoptera: Thripidae). Bull. Entomol. Res. 89:579-588. 